\title{
CLUSTERS, EUROPEAN POLICY IN EXCELLENCE OF MANAGEMENT
}

\author{
Florina Bardea ${ }^{1}$, Felix H. Arion ${ }^{2}$, Patryk Szabelski ${ }^{3}$
}

\begin{abstract}
The European Union (EU) plays an important role in the developing of clusters, defined by the European Commission as groups of specialized enterprises - often SMEs - and other related supporting actors that cooperate closely together in a particular location. As a result, the EU launched the pan-European initiative to support cluster management (European Cluster Excellence Initiative). It recognizes the performance of cluster management by quality labels such as the Bronze, Silver, and Gold issued by The European Secretariat of Cluster Analysis. With reference to these certifications, the authors analyzed the cluster management excellence by critically studying the labels granted in terms of trends, numbers, sectors, countries, and regions. Based on the gathered results, the clusters initiatives (new or already existed) can benchmark themselves. Regional, national, and European policymakers will be able to estimate how specific factors of political, geographical, demographic, access to raw materials, and level of development can influence the number of clusters, their quality of management, and cluster typology. The goal of the research is to identify the number and type (bronze, silver, and gold label) of clusters in the EU and UK. As research methods, analyzes were performed using the European Cluster Collaboration Platform (ECCP) and European Secretariat for Cluster Analysis (ESCA) data. The main results of the research show that clusters differ not only in size or activity but also in quality. Most clusters are found in the rich countries of Western Europe. Most clusters in Europe that have a bronze label are often located on the Iberian Peninsula, the Balkans, and Central Europe.

JEL Classification Numbers: H5, M21, O3, DOI: https://doi.org/10.12955/peb.v1.10
\end{abstract}

Keywords: cluster, policy, quality, European Union, national legislation

\section{Introduction}

The clustering phenomenon has gained momentum in recent years, with more studies being undertaken on cluster formation initiatives. Because for some countries, cluster structures are a new concept, the example of the European countries and beyond, which have strongly developed clusters, can be a starting point for initiating such actions. Also, depending on the stage of cluster development, cluster policies will need to develop. For example, in the incipient phase of the clusters, the important aspects concern the development of specialized research, the infrastructure, the encouragement of connections, the development of the company's capabilities and the elaboration of a common vision. In the growth phase of the clusters, the emergence of new companies may lead to the modification of certain strategic alliances regarding the research and development activities of the cluster or may require new strategies to meet the increased demand for skilled labor force. The emergence of foreign competitors or competing technologies may require internal cluster restructuring to increase efficiency or a new investment in research and development. This dynamism causes the cluster structure to change over time (Arthurs et al., 2009).

In today's world, not only is innovation a condition for the economic success but it is also essential for the enterprise to survive competition in the market. Innovation brings together several actors involved in innovative systems, such as businesses, universities and research institutions, public authorities, and regional authorities. Clusters have multiple effects on innovation, such as increasing productivity and providing innumerable opportunities for new companies with lower entry levels - all of which will improve the connection between the members of a cluster (Maticiuc, 2015).

When we talk about co-operation, we automatically talk about a dialogue between several individuals or groups, where information is exchanged. On this premise, clusters based on the co-operation of some groups, enterprises, universities, state institutions were born in order to obtain mutual benefits from this co-operation. With their development, the necessity to classify them has arisen, and the best method to do so will be by their cluster quality. In this context, the European Union has come to support these forms of cluster organizations by strengthening the excellence of a cluster. The European Cluster Excellence Initiative, which has introduced Cluster Management Excellence Label Bronze, Silver, Gold, has helped establish excellence in cluster structure, management, funding, service strategy, and recognition. These labels certify cluster organizations that demonstrate highly sophisticated cluster management. The purpose of the research is to identify the number and type (bronze label, silver label,

\footnotetext{
${ }^{1}$ University of Agricultural Sciences and Veterinary Medicine Cluj-Napoca, Romania, florina.deiac@usamvcluj.ro

${ }^{2}$ University of Agricultural Sciences and Veterinary Medicine Cluj-Napoca/AgroTransilvania Cluster, Romania, felixarion@usamvcluj.ro

${ }^{3}$ Poznan University of Life Sciences, Poznan, Poland, szbe194@gmail.com
} 
and gold label) of clusters in the European Union. The European policies play a vital role in developing clusters, as they are the future engine of the global economy.

\section{General considerations about clusters}

Historically, the cluster term was mentioned by Alfred Marshall in 1920, which concluded that organizations and companies around London were interconnected with three main factors: the workforce, specialized providers, and access to information (Dan, 2012). The cluster concept is based on the idea of an "industrial district", as explained by A. Marshall by the end of the nineteenth century, in the Principles of Economics in 1890. Marshall (1890) describes three essential characteristics of the cluster: the provision of specialized work, the development of auxiliary and service branches, and the specialization of enterprises for different production processes.

As Porter described (1998) "Clusters are geographic concentrations of institutions and related companies in a particular field. Clusters include a group of related industries and other important entities from a competition point of view" (Porter, 1998). Communication from the European Commission COM (2008) 652/2008 "Towards world-class clusters in the European Union implementation of the innovation strategy" defines the cluster as a group of companies, connected economic actors and institutions located in geographical proximity, to the extent necessary for the development of specialized expertise, services, abilities and suppliers (Coşniţă, 2013).

Economic literature defines several types of clusters according to economists' thinking. From the structure of the clusters, Markusen (1996) delimited three types clusters: network clusters (industrial district), node and hub clusters (hub and spoke), and satellite clusters. Subsequently, the institutional cluster was added to them (Paytas et al., 2004). The network cluster (industrial district) is characterized by the domination of small companies, intense competition, deep specialization. An example of this is Silicon Valley, Boston (Route 127) in USA and northern Italy (Hospers, 2005). Hub and spoke cluster is characterized by the coexistence of large local companies related to a large group of companies in the sector small and medium-sized enterprises, for example, Toyota City or Seattle- Boeing. From another point of view, according to the agglomeration model, which is based on the concept of the Local Production Network Paradigm (LPNP) analyzed by Simmie and Hart (1999) there are three types of clusters: Cohesive Cluster, New Industrial Districts, and Innovative Milieux. Cohesive Clusters are characterized by a group of organizations that collaborate on a common location that allow them to reduce costs; New Industrial Districts promote collaborative knowledge-based schemes including a high share of computer enterprises, information technology and microelectronics. Innovative Milieux cluster is mainly located in urban areas where there are close relationships between individuals and businesses. The last type of cluster is the proximity cluster characterized by a higher degree of internal heterogeneity in terms of organization production rather than cohesion (Hart, Simmie, 1999). This type of cluster may include many micro-enterprises (e.g., Hertfordshire).

The researchers describe six basic clustering objectives: research and networking, political action, commercial co-operation, education and training, innovation and technology, and cluster expansion (Prodan M. 2015). The main advantages of the cluster organization are innovation, market access, infrastructure, human resources, resources, financial resources, proximity, transaction cost reduction, and image enhancement (Tanţău, 2011). Often public authorities use instruments to stimulate cooperation between local people and help them to create clusters. Each cluster of different size and specialization must go through various stages of development. The cluster development process has several stages (Staszewska, 2009) and, a critical role in all stages of the development of the cluster is given by individual enterprises, each with specific characteristics. The government must ensure that the issues of public interest are not ignored and should not act as a genie of a lamp that "' fulfills all the wishes of the cluster (Ebbekink et al, 2013). At this international competition of strategic initiatives, Romania has participated from a lesser position than the other European countries. The Romanian state used several tools as part of the regional and industrial policy to create or facilitate "public clusters" (Pîslaru et al., 2005). The European Commission embraced the concept of clusters, especially the implementation of regional policy and the development of the Lisbon agenda. Thus, it supported the mapping exercise, such as the European Cluster Observatory and networking between cluster initiatives (Uyarra et al., 2012). 


\section{Material and Methods}

As for the materials used, the research included European clusters, analysis of European Union cluster policies, the study of tools that support the development of clusters, the study of the distribution, quantity, quality level, and industry type. As research methods, analyzes were performed using the European Cluster Collaboration Platform (ECCP) and European Secretariat for Cluster Analysis (ESCA) data. These data were used to analyze the quantity, quality, and distribution of clusters in Europe. The European Union (EU) plays an important role in developing clusters, defined by the European Commission as being groups of specialized enterprises - often SMEs - and other related supporting actors that cooperate closely together in a particular location. At the European Union level, there are three types of cluster policies, namely facilitation policies, framework policies, and development policies. Facilitation policies aim to create a microeconomic environment conducive to growth and innovation that stimulates the emergence of clusters. Framework policies directly target industry, SMEs, research, and innovation that often use the cluster to increase the efficiency of a specific instrument. Development policies encourage the creation, mobilization, and consolidation of initiatives to cluster (Dan, 2012). What makes the clusters potentially beneficial for the competitiveness of SMSs are the opportunities to obtain collective efficiency (Gerolamo et al., 2008). The activities of the European Commission for clusters are focused on four pillars, and that includes different initiatives. The first pillar includes the initiative named Cluster Observatory (European Cluster Observatory). The undertaking is a continuation of the project financed by CIP within the framework of Europe INNOVA and aims to provide statistical information, a tool for mapping clusters and analyses on European clusters and cluster policy in Europe.

The group of users includes cluster policy at the national level and regional level, organizations representing SMEs, and cluster managers. The second pillar includes Cluster excellence. The project is a continuation of the ECEI (European Cluster Excellence Initiative). It includes the following initiatives: training for trainers (train-the-trainers) and for cluster managers, made by the European Foundation for Cluster Excellence, responsible for updating the most important materials and organizing training, (http://www.clusterexcellence.org/) and awarding clusters with badges for management quality (bronze, silver, gold labels). The European Secretariat for Cluster Analysis (ESCA) constantly improves and updates the benchmarking tool. (http://www.cluster-analysis.org/). The third initiative is based on internationalization (Cluster internationalization).

European Strategic Cluster Partnerships. The initiative to create European Strategic Cluster Partnerships (ESCP) created new business opportunities and market opportunities for entrepreneurs, mainly SMEs. The main goal of a partnership is the co-operation of clusters and networks removing the geographical and sectoral boundaries, which is to lead to the creation of new value chains in the economy, covering companies from various sectors, as well as to provide better support for SMEs in global competition. The partnerships are expected to work on solutions that respond to societal challenges. Because these are issues beyond the capabilities of a single cluster or network, such cross-sectoral and transnational projects may prove to be an effective solution.

The European Cluster Collaboration Platform. The EC has to continue to run ECCP, which is a tool designed for managing in different clusters and cluster members. EC activities include site networking tools and renewal to give people the most significant value of co-operation. The use of ECCP is free, and logged-in users can use several functions

The fourth pillar includes new industries (Emerging Industries). The European Commission promotes co-operation between clusters and companies from a lot of industries and branches. Implementation of activities in this area take place by analyzing the emerging industries and tools for mapping clusters in new sectors, supporting the creation of cross-sectoral innovation and innovationrelated to new value chains using clusters, supporting testing of cluster policy tools and instruments supporting mutual learning (policy learning), and providing information on European initiatives that support the emergence of new industries.

\section{Results and Discussion}

Cluster policy approaches. Clustering has become an essential element of the innovation policy in the European Union Member states supporting an approach based on innovative regional clusters, not only in developed urban centers but also in poorer or rural regions (Popa and Popescu, 2013). In conclusion, 
the cluster is one of the best tools for the challenges of development (Gagnidze, 2015). In developed countries, the high standard of living leads to the desire to maintain their long-term achievements. In less developed countries, the desire is to reach a high standard of living, to develop. Thus, clusters are instruments of regional, national, European policies, meant to contribute to the continuous process of developing nations.

State of fact of EU clusters (ECCP). Most of the clusters are located in southern and central Europe, such as Portugal, Spain, Italy, France, Germany, and in the Benelux countries. The reason for this preference to location is because the high level of development of these regions resulting in highly developed industries. The number of clusters in a region are by the climate, the relief, the culture, soil quality, the availability of natural resources, and the country's policy. The availability of funds for the development of enterprises and clusters and the possibility of obtaining financial resources from the European Union or government programs is also important.

Clusters differ not only in size or activity but also in quality. Most clusters in Europe have a bronze label, mostly are located on the Iberian Peninsula, the Balkans, and Central Europe. The location of the silver label of clusters is different from the distribution of the bronze label clusters. Most of them are located in Switzerland and Austria, Northern Italy, Germany, and Romania. The best clusters, implying the gold label clusters, are found mainly in France, Germany, Spain and Scandinavia. Several can also be found in south-eastern Europe. The last group of clusters are labelled as 'other'. They are located throughout Europe and Scandinavia. Ecological activities are also important for the European Union's policy. Europe has several enterprises and environmentally friendly clusters. They are located throughout Europe and are found predominantly in Germany, Spain, Italy, and the Balkan Peninsula.

Methods of evaluating the excellence in cluster policies created by ESCA.

In 2009 the European Commission propelled The European Cluster Excellence Initiative (ECEI) under The Competitiveness and Innovation Program and was a consequence of the European Union's endeavors to make increasingly world-class clusters over the EU by strengthening the group. This skillet strategic European activity included 13 members from nine European nations ESCA-The European Secretariat for Cluster Analysis, was set up by one of the accomplices VDI/VDE Innovation + Technik $\mathrm{GmbH}$, to offer pragmatic counsel to group the executives' associations. In these days, ESCA is a system of group specialists from more than 30 nations.

With regards to the idea of "world-class group", cluster management excellence relies upon the accompanying components, for example, the presence and usage of a technique for the further advancement of the cluster, the arrangement of expert administrations that address the necessities of the cluster members through cluster management, economical financing of the cluster members association, and proper staffing of the association and additionally. (Lämmer-Gamp, 2011).

A procedure for cluster benchmarking, which is recognized by the two clusters and implemented all through Europe, was created by the ESCA specialists. Using this approach, more than 450 cluster management organizations have been benchmarked since 2008 (Hatsch, 2013). There are three kinds of benchmarking marks that clusters can get: bronze name, silver name, and gold name. Bronze is not a sign of quality but shows the cluster's interest in improving the efficiency of management and development. However, it is the first step towards improving the quality of cluster management. The silver label confirms the improvement of the cluster's quality, its management, and its development. It also shows the willingness to enter the next level and obtain a golden label in the future and aim for excellence. It was introduced in the summer of 2014 and is still in its pilot phase. The highest level of quality is Gold label; it sets very high standards in the cluster (Lammer G,2014). Benchmarking used by ESCA consists of the following elements: benchmarking interview, analysis of 36 indicators - they concern various aspects of the company's operations, benchmarking report, large portfolio, and confidentiality. The indicators used for evaluation include a set of indicators of quality:

1) Structure of the cluster,

2) Typology, Governance, Cooperation,

3) Financing Cluster Management,

4) Strategy, Objectives, Services,

5) Achievements and Recognition (Lammer, 2014). 
The concept of quality management is a crucial factor in organizational success and survival (Sadeghi et al., 2018). Figure 1 and 2 show the number and percentage of certification of European clusters, which were at the beginning of 2020 .

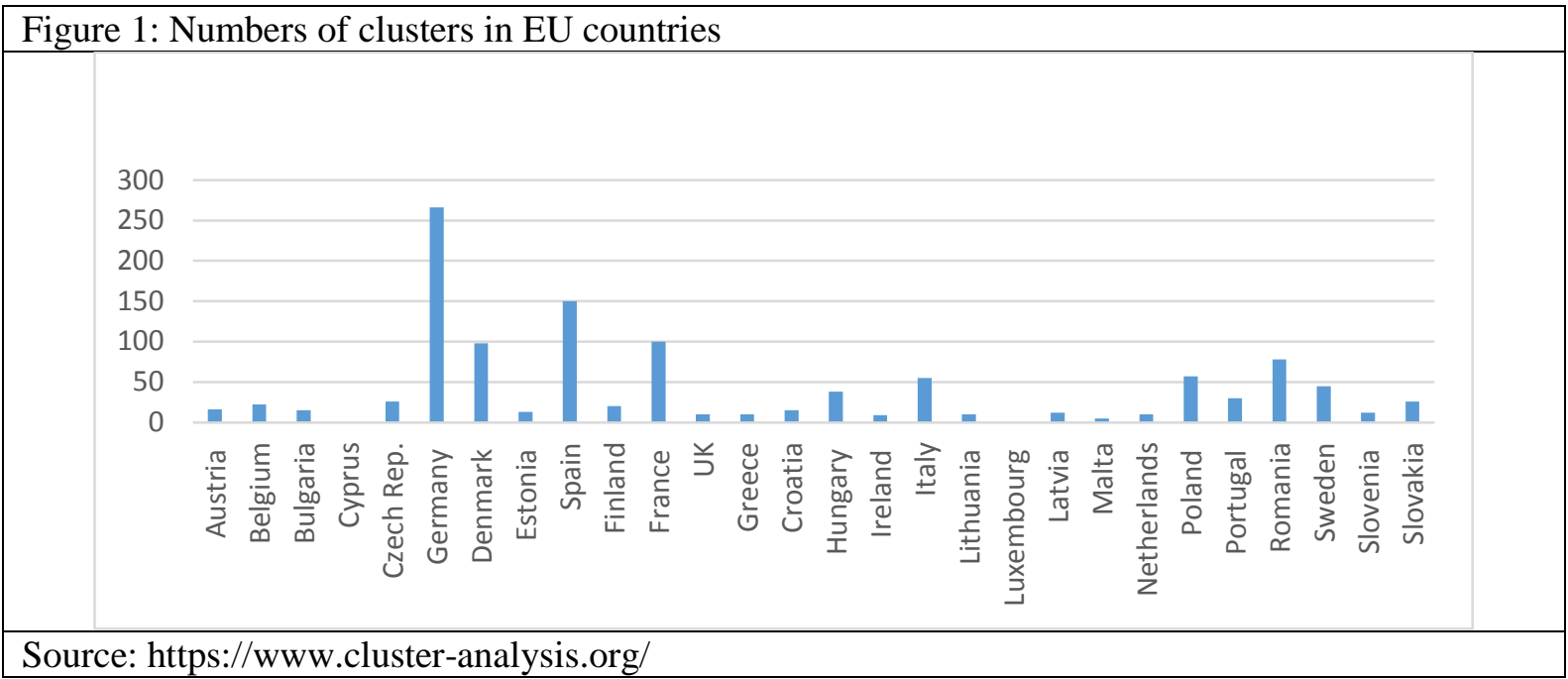

\section{Figure 2: Percentage of clusters in the total number of clusters in the country}

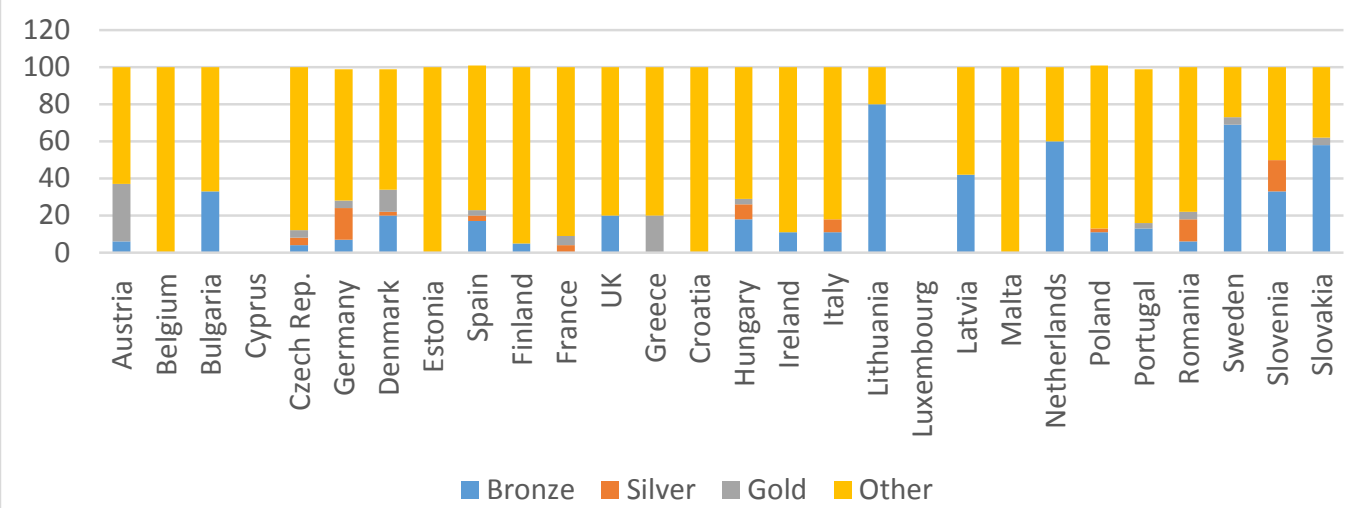

Source: https://www.cluster-analysis.org/

From the graphics above, we observe the largest number of clusters are in Germany-266, Spain-150, France-100, and Denmark-98. The smallest number of clusters are in Luxembourg -0, Cyprus-0 and, Malta-5. The most Bronze clusters can be found in Sweden-31, Spain - 25, Denmark-20, Germany-19, and Slovakia-15. The smallest number of clusters are in such countries as Austria-1, Czech Republic-1, Finland-1, UK-2, Ireland - 1, Estonia-0, Greece -0, and Croatia -0.

Therefore, the number of clusters of higher quality is more important for the study. The largest number of silver clusters is in Germany-46 and Romania-9. The lowest number of clusters is Denmark-2, Czech Republic-1, Poland-1 and Slovenia-2. Gold clusters are identified with the highest management quality. Achieving such a label is difficult but very prestigious. The largest number of gold clusters is in Denmark-12, Germany -11, Austria -5, France-5, Spain-4 and Romania-3. The lowest in Sweden-2, Greece - 2, Hungary -1, Slovakia -1, Czech Republic -1 and Portugal-1. There are also clusters in each country that do not have any excellence labels. On the other hand, they have other stickers assigned by the state authorities or regional authorities. The largest number of such clusters is in Germany-190, Spain -117, France-91, Romania-61, Poland-50, and Italy -45. The least is in countries like Latvia-7, Lithuania-2, Slovenia-6, Greece-6, Malta-5, and Netherlands-4. The only countries that do not have such clusters are Cyprus and Luxembourg. It is related to the policy and the type of business that is conducted in these countries. Due to differences in the size and wealth of these countries and the specifications of production, analysis of the distribution of particular types (bronze, , and gold) is more important. For the country, it is important to have the maximum possible number of gold clusters and also ensure that their share in the total number of clusters is the largest. On the other hand, the large number (and share) 
of brown clusters does not mean that the country is poor and poorly-developed and that it houses badly managed clusters, but it shows that the clusters are uniting and are demonstrating a willingness to improve. The largest share of bronze clusters is in such countries as Lithuania-80\%, Slovakia-58\%, Latvia-42\%, Bulgaria, and Slovenia-33\%, Denmark, and UK-20\%, Hungary-18\%, and Spain-17\%. The smallest share of clusters is in Ireland, Italy, and Poland-11\%, Austria and Romania - 6\%, Finland-5\%, and Czech Republic-4\%. In Belgium, Estonia, Greece, Croatia, France, and Malta, brown clusters constitute $0 \%$. Another group of clusters is silver clusters. Their largest share is in Germany and Slovenia, where they account for $17 \%$ of all clusters, Romania - $12 \%$, Hungary- $8 \%$, and Italy $-7 \%$. The smallest share can be found in France and Czech Republic-4\%, Spain-3\%, Denmark, and Poland-2\%. Another group of clusters is the golden clusters that are the most important and the most prestigious for the national economy. Their largest share is found in Austria - 31\% of the total number of clusters, Greece-20\%, and Denmark -12\%. They are the smallest in France-5\%, Germany, Romania, Sweden, Slovakia and Czech Republic-4\%, Spain, Portugal, and Hungary-3\%.

The last group is Other clusters. In the case of countries with a larger number of clusters, the largest share of Other clusters is in Germany-71\%, Spain-78\%, France-91\%, Denmark-65\%, Italy-82\%, Poland- $88 \%$, and Romania-78\%. The smallest share is in Netherlands-40\%, Sweden-27\%, and Lithuania-20\%. There is no cluster in this label in Cyprus and Luxembourg.

\section{Conclusions}

The importance of clusters in the regional, national, and global economy is continuously changing. The participation of enterprises in clusters allows for the increase of prestige and brings many economic and managerial benefits. More and more businesspeople strive for the excellence of their companies. Participation in the cluster allows them to obtain or improve a management system, technology, or workforce. It also improves competitiveness in the market. Several clusters are emerging not only in Europe but throughout the world. The desire to develop and also obtain funds to effect development is the main reason for creating a cluster.

Currently, an upward trend is observed regarding the number of clusters or their sizes. In economically backward and lesser developed countries, it is more challenging to obtain funds for creating a cluster. On the other hand, there is less competition in such countries, which may lead to an easier route to higher profits, but it is often limited by poor access to technology, educated employees, and access to business partners. In wealthier countries, it is a source of financial resources, technology, and employees, but the problem may be due to the bureaucracy or big competition in the market where the enterprise or the association operates. Currently, there are many clusters with the lowest quality label, bronze, but it does not mean that they work in a less efficiently or are poorly managed. It is a positive indication that they want to grow, increase their profits, and ultimately strive for perfection. In future, the number of clusters is likely to increase, and the size of the current clusters may increase.

In the countries of the European Union, it is observed that more and more clusters are being created, and the existing ones are being improved in order to obtain a higher quality label. However, it is still noticeable that most clusters are found in the rich countries of Western Europe, such as Denmark, Spain, France, Germany, or Italy. They are characterized by a large number of clusters and large shares of gold clusters. Important countries distinguishing themselves from other countries in Central and Eastern Europe are Poland and Romania. They have a large number of clusters that are bronze clusters or those with "other" quality labels issued by the country or local authorities. A large number of these clusters are visible in such countries as Spain, Italy, France, and Germany. However, Romania also has a large number of clusters in this sector.

European certifications are known under several labels and represent European recognition for the outstanding performance of an organization. With the help of some indicators, performance is measured in the organization's management. Such European certifications are needed in Romania because they can be defined as the passport for developing partnerships and projects at the European and international level.

\section{References}

Arthurs, D., Cassidy, E., Davis, C. H., \& Wolfe, D. (2009). Indicators to support innovation cluster policy. International Journal of Technology Management, 46(3-4), 263-279.

Coşniţă, D., \& Iorgulescu, F. (2013). Analiza competitivităţii clusterelor din România. 
Mihaela-Cornelia, Dan. (2012). Clusterele inovative: o soluţie pentru dezvoltarea economică a României. Economie teoretică şi aplicată Volumul XIX, (9), 574.

Ebbekink, M., \& Lagendijk, A. (2013). What's next in researching cluster policy: Place-based governance for effective cluster policy. European Planning Studies, 21(5), 735-753.

European Foundation for Cluster Excellence, Retrieved February, 28,2020, from http://www.clusterexcellence.org/

Gagnidze, I. (2015, October). Cluster as a tool for the challenges of development. In Strategica International Academic Conference, Third Edition 'Local versus Global', Bucharest, Romania, October (pp. 29-31).

Gerolamo, M. C., Carpinetti, L. C. R., Seliger, G., \& Galdamez, E. V. C. (2008). Performance management of regional clusters and SME cooperation networks. International Journal of Business Excellence, 1(4), 457-483.

Hatsch, S., \& Kergel, H. (2013). Cluster management excellence in Germany. Berlin: European Secretariat for Cluster Analysis (ESCA).

Hospers, G. J. (2005). Best practices'and the dilemma of regional cluster policy in europe. Tijdschrift voor economische en sociale geografie, 96(4), 452-457.

Ketels, C., Lindqvist, G., \& Sölvell, Ö. (2012). Strengthening clusters and competitiveness in Europe. The Role of Cluster Organisations. The Cluster Observatory, 56.

Lämmer-Gamp, T., Kergel, H., \& Nerger, M. (2014). Cluster organisations in Europe-insights from Bronze and Gold Label assessments. Berlin: European Secretariat for Cluster Analysis.

Lämmer-Gamp, T., zu Kôcker, G. M., \& Christensen, T. A. (2011). Clusters are individuals: Creating economic growth through cluster policies for cluster management excellence. Danish Ministry of Research, Innovation and Higher Education.

Markusen, A. (1996). Sticky places in slippery space: a typology of industrial districts. Economic geography, 72(3), 293-313.

Maticiuc, M. (2015).Innovation-an useful tool for cluster development. 1. Bogdan Oana, 26, 123.

Paytas, J., Gradeck, R., \& Andrews, L. (2004). Universities and the development of industry clusters. Carnegie Mellon University, Center for Economic Development.

Pîslaru, D., \& Aristide, O. (2005). Către o politică industrială bazată pe aglomerări economice competitive-clustere. Revista OEconomica, (03).

Porter, M. E. (1998). Clusters and the new economics of competition (Vol. 76, No. 6, pp. 77-90). Boston: Harvard Business Review.

Popa, I., \& Popescu, D. (2013, November). The importance of innovative clusters' proliferation for sustainable economic growth of Romania. In Proceedings of the 7th international management conference New Management for the New Economy. Popescu, C. (2010). Industrial clusters and regional development in Romania. Human Geographies--Journal of Studies \& Research in Human Geography, 4(2).

Prodan, M. (2015). Evoluţia concepţiei despre clusterele economice şi avantajele clusterizării. http://irek.ase.md/xmlui/bitstream/handle/123456789/121/Prodan-M_8-mai-2015.pdf-12.pdf?sequence=1\&isAllowed=y

României, G. (2014). Planul national de dezvoltare 2007-2013, http://old.fonduri-ue.ro/documente-programare/pnd-2007-2013

Simmie, J., \& Hart, D. (1999). Innovation projects and local production networks: a case study of Hertfordshire. European Planning Studies, 7(4), 445-462.

Sadeghi Moghadam, M. R., Safari, H., \& Yousefi, N. (2018). Clustering quality management models and methods: systematic literature review and text-mining analysis approach. Total Quality Management \& Business Excellence, 1-24.

Staszewska, J. (2009). Klaster perspektywą dla przedsiębiorców na polskim rynku turystycznym. DEFIN.

Tanţău, A. D. (2011). Ghid de bună practică pentru clustere şi reţele de firme. Bucureşti: Print Grup, available at http://www. inmaita.ro/2_Ghid_buna_practica_pentru_clustere_si_retele_de_firme.pdf, retrieved on, 8, 2013.

The European Secretariat for Cluster Analysis (ESCA) (2020) Retrieved March, 15, 2020 from https://www.clusteranalysis.org/

Uyarra, E., \& Ramlogan, R. (2012). The effects of cluster policy on innovation. Retrieved from https://www.nesta.org.uk/documents/159/the_effects_of_cluster_policy_on_innovation.pdf 